\title{
Molecular Characterization and Antibiotic Resistance Pattern of Nosocomial Clinical Isolates in Southeast of Iran
}

\author{
Farzaneh Mohammadzadeh Rostami \\ (PhD) \\ Department of Bacteriology and \\ Virology, Faculty of Medicine, Isfahan \\ University of Medical Sciences, \\ Isfahan Iran \\ Saman Shalibeik (PhD) \\ Department of Microbiology, \\ Falavarjan Branch, Islamic Azad \\ University, Isfahan, Iran \\ Morteza Rabi Nezhad Mousavi \\ (MSc) \\ Department of Microbiology, Zahedan \\ University of Medical Sciences, \\ Zahedan, Iran \\ Corresponding author: Morteza Rabi \\ Nezhad Mousavi \\ E-mail: \\ Rabi.nezhad.mousavi@gmail.com \\ Tel: +989367227692 \\ Address: Department of Microbiology, \\ Zahedan University of Medical \\ Sciences, Zahedan, Iran
}

Received: 29 May 2018

Revised: 01 Jun 2019

Accepted: 03 Jun 2019

cc) (i) (8)

This work is licensed under a Creative

Commons Attribution 4.0 License.

\section{ABSTRACT}

Background and objectives: Nosocomial infections caused by antibiotic resistant bacteria is a life threatening health challenge. This study aimed to determine the frequency of antibiotic resistance genes in clinical isolates from hospitals of Zahedan, southeast of Iran.

Methods: 0verall, 818 isolates were collected from different hospital wards. The isolates were identified using conventional microbiological and biochemical tests. Antibiotic susceptibility pattern was assessed by agar disc diffusion method and determination of minimum inhibitory concentration of a number of antibiotics. Multiplex PCR was performed using specific primers for the detection of resistance genes.

Results: The most common species were Staphylococcus aureus (25\%), Klebsiella pneumoniae (22\%) and Pseudomonas aeruginosa (14\%). The rate of methicillin resistance among $S$. aureus, $S$. epidermidis and $S$. saprophyticus was $60 \%, 43 \%$ and $24 \%$, respectively. In addition, 28.5\% of enterococci isolates were vancomycin resistant. Among gram-negative bacteria, $45 \%$ of $A$. baumannii and $24 \%$ of $P$. aeruginosa were identified as ESBL. A high level of resistance to ampicillin (96\%), cefotaxime $(89 \%)$, gentamicin $(89 \%)$ and sulfamethoxazole-trimethoprime (60\%) was observed in K. pneumoniae.

Conclusion: 0ur results highlight the urgent need for an eradication program and a surveillance plan for preventing increased emergence of antibiotic resistant bacteria in the study area.

Keywords: Bacterial Infections, Drug resistance, Zahedan.

This paper should be cited as: Mohammadzadeh Rostami F, Shalibeik S, Rabi Nezhad Mousavi M [Molecular Characterization and Antibiotic Resistance Pattern of Nosocomial Clinical Isolates in Southeast of Iran]. mljgoums. 2020; 14(1): 20-28 


\section{INTRODUCTION}

Nosocomial infection is an infection that is acquired in a hospital. Surgery, transplantation and hospitalization in the pediatric ward, intensive care unit (ICU) and cardiac care unit $(\mathrm{CCU})$ are some of the risk factors for nosocomial infections $(1,2)$. A large number of both gram-positive and gramnegative bacteria including Staphylococcus spp., Enterococcus spp., Pseudomonas aeruginosa, Acinetobacter baumannii and Enterobacteriaceae can cause various hospital-acquired infections such as urinary tract infection, bacteremia, wound infection, gastrointestinal infection, etc. (3-6). Furthermore, the emergence of methicillinresistant $S$. aureus (MRSA), vancomycinresistant enterococci (VRE), extendedspectrum $\quad \beta$-lactamase $\quad$ (ESBL) Enterobacteriaceae spp. and multi drug resistant (MDR) strains has become a major challenge to treatment of nosocomial infections (7-9). Hence, the World Health Organization (WHO) has released a global priority list of antibiotic-resistant bacteria to help prioritize research and development of new and effective antibiotic treatments $(8,9)$. The primary objective of this study is to evaluate the prevalence of nosocomial infections and determine involved bacteria and their antibiotic resistance genes in Zahedan, southeast of Iran.

\section{MATERIAL AND METHODS}

Bacterial isolates associated with nosocomial infections were collected from four hospitals in Zahedan (southeast of Iran) during 2014-2016. The samples were collected from different wards including ICU, CCU, pediatric ward, internal medicine ward and general surgery and transplantation ward. This study was conducted in accordance with the principles of the Declaration of Helsinki and was approved by the ethics committee of the Zahedan University of Medical Sciences.

The bacterial isolates were identified by culture, gram staining, morphological assessment and biochemical tests such as catalase, oxidase, oxidation/fermentation, salt tolerance, coagulase reaction, hemolysis, esculin hydrolysis, growth on MacConkey agar, IMViC, decarboxylases, sugar fermentation, malonate, DNase, motility, indole production, hydrogen sulfide production and reaction in triple sugar iron agar, etc. All isolates were then stored in Mueller Hinton broth with $30 \%$ glycerol at -70 ${ }^{\circ} \mathrm{C}$ for analysis. All culture media and reagents were purchased from Merck Co., Germany. Antibiotic susceptibility was assessed by the disk diffusion method. Minimum inhibitory concentration (MIC) of the following antibiotics was determined using E-test strips (Liofilchem, Italy) according to the Clinical and Laboratory Standards Institute (CLSI) recommendations: tetracycline, erythromycin, clindamycin, chloramphenicol, ampicillin, oxacillin, methicillin, piperacillin and piperacillin/tazobactam, azteronam, ceftriaxone, ceftazidime, cefepime, cefotaxine, cefexime, ciprofloxacin, gatifloxacin, norofloxacin, levofloxacin, ofloxacin, nalidixic acid, cotrimoxazole, imipenem, meropenem, gentamicin, amikacin, tobramycin, kanamycin, fosfomycin, vancomycin, linezolid, nitrofurantoin, quinupristin/dalfopristin and collistin. All antibiotic disks were purchased from Mast Co., UK.

The double disk synergy test was performed to evaluate ESBL production. In this test, augmentin $(20 \mu \mathrm{g}$ amoxicillin and $10 \mu \mathrm{g}$ clavulanic acid) and third-generation cephalosporins (ceftazidime $30 \mu \mathrm{g}$, ceftriaxone $30 \mu \mathrm{g}$, cefotaxime $30 \mu \mathrm{g}$ ) disks are kept $30 \mathrm{~mm}$ apart, center to center, on inoculated MuellerHinton agar (MHA). A clear extension of the edge of the inhibition zone of cephalosporin towards augmentin disk is interpreted as positive for ESBL production. After incubation at $35 \pm 2{ }^{\circ} \mathrm{C}$ for $18 \mathrm{~h}$, ESBL positivity was confirmed by observing increased inhibition zone around one of the four antibiotic disks toward amoxicillinclavulanic acid. Susceptibility cut-offs were considered according to the CLSI. Escherichia coli ATCC 25922, E. coli ATCC 35218, E. coli ATCC25922, $P$. aeruginosa ATCC 27853, Klebsiella pneumoniae ATCC700603, Enterococcus faecalis ATCC29212, S. aureus ATCC33591 and S. aureus ATCC 25923 were used as control strains.

After $18 \mathrm{~h}$ at $35 \pm 2{ }^{\circ} \mathrm{C}$, chromosomal and plasmid DNA were extracted using a mericon DNA bacteria kit (Qiagene, Germany) according to the manufacturer's instructions. The quality and quantity of the extracted DNA were tested by gel electrophoresis and spectrophotometry, respectively. Genotypic identification of each clinical isolate was 
carried out by PCR using specific primers (Table 1) and results were confirmed by biochemical tests. Then, multiplex PCR was used for detection of antibiotic resistance genes using specific primers (Table 2) for each species. Multiplex PCR was performed in a final volume of $25 \mu \mathrm{L}$ containing $1 \mu \mathrm{L}$ of each primer $(0.3 \mathrm{mM}), 12 \mu \mathrm{L}$ of PCR Master Mix (Fermentase, Denmark), $0.05 \mathrm{U} / \mu \mathrm{L}$ taq DNA polymerase, $0.4 \mathrm{mM}$ dNTPs, $4 \mathrm{mM} \mathrm{MgCl} 2$ and $1 \mu \mathrm{L}$ template DNA. The cycling conditions for 10 minutes, 35 cycles of denaturation at 94 ${ }^{\circ} \mathrm{C}$ for 30-60 seconds, annealing at $56{ }^{\circ} \mathrm{C}$ for 35 seconds, extension at $72{ }^{\circ} \mathrm{C}$ for $30-60$ seconds and final extension at $72{ }^{\circ} \mathrm{C}$ for $5-10$ minutes.

DNA sequencing was performed by Macrogen Co., South Korea for appraising highest purity and accuracy of antibiotic resistance genes. The obtained sequences were aligned and compared to data available at GenBank (NCBI).

Figure 1 -Frequency of clinical isolates collected from hospitals of Zahedan, Iran. UC: urine culture; BC: blood culture; W: wound infection; Uca: urine catheters; Ett: endotracheal tube; csf: cerebrospinal fluid

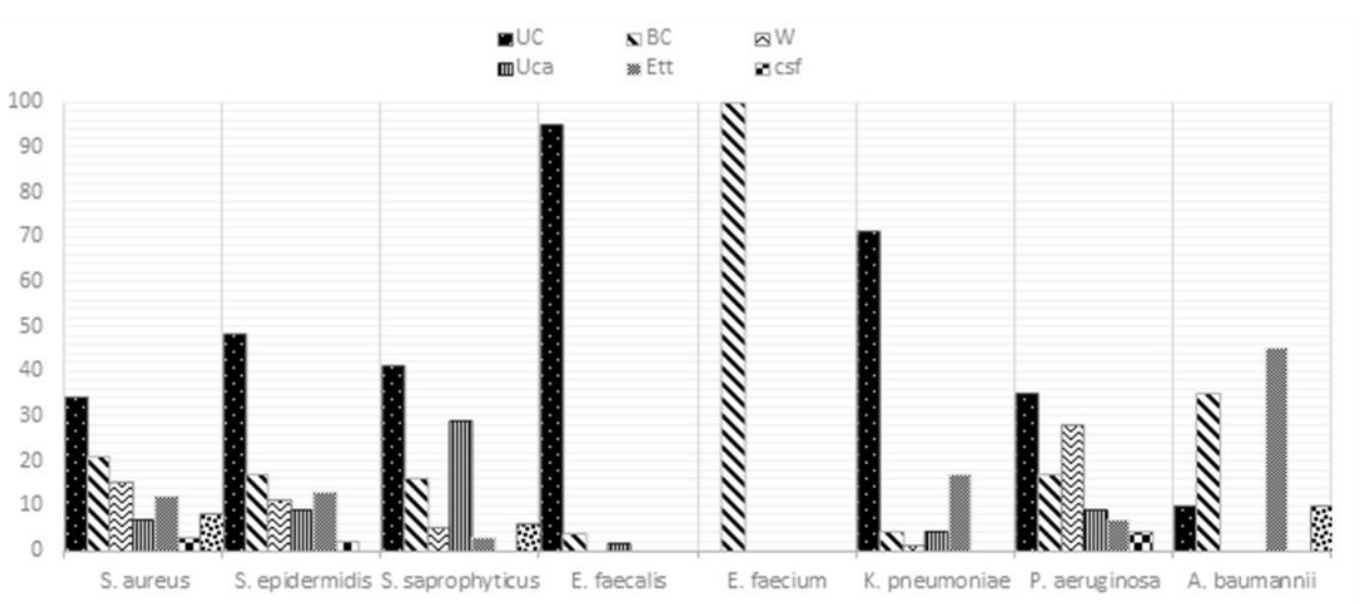

Figure 2- Antimicrobial susceptibility patterns among gram-positive isolates. VAN: vancomycin; AMP: ampicillin; IMI: imipenem; SYN: quinupristin/dalfopristin (Synercid $\left.{ }^{\circledR}\right)$; ERY: erythromycin; TET: tetracycline; CHL: chloramphenicol; FOS: fosfomycin
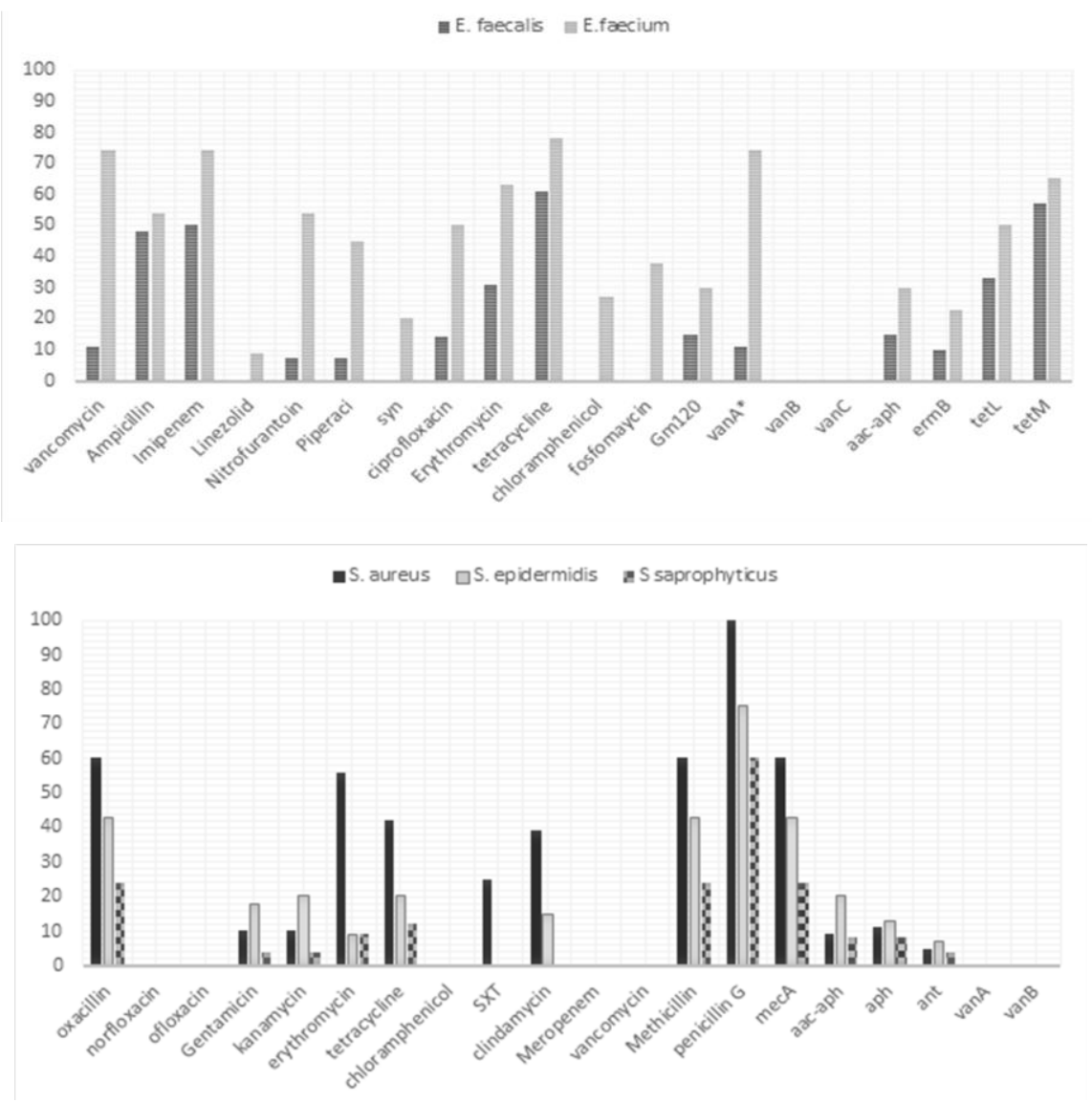
Figure 3-Antimicrobial susceptibility patterns among gram-negative isolates

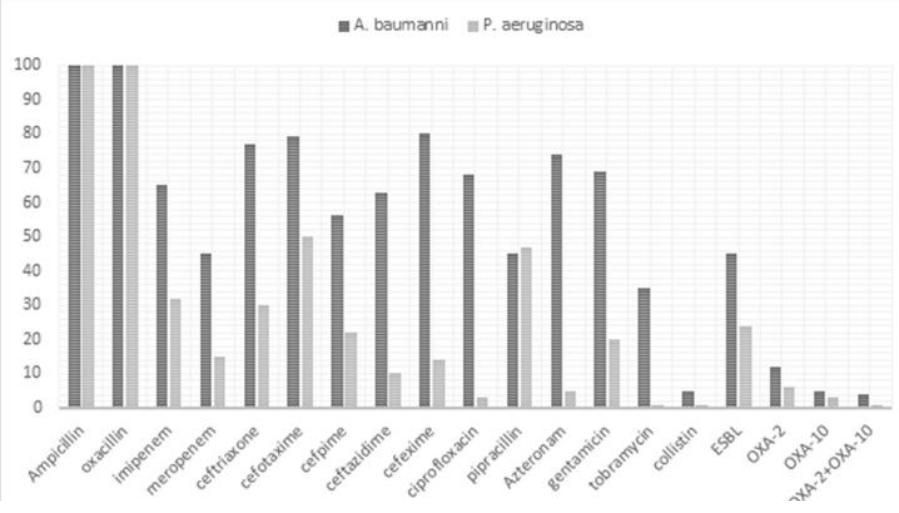

K. PNUMONIAE

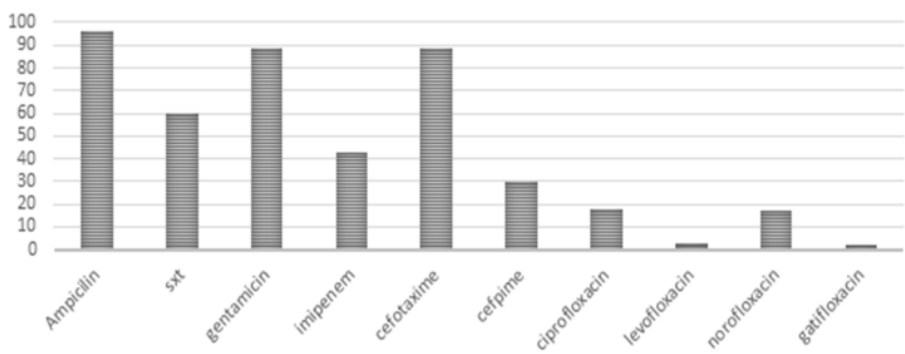

Table 1- Partial 16S rDNA sequences of the specific primers used in the study

\begin{tabular}{|c|c|c|c|}
\hline Bacterium & Primer sequence (5-3) & $\begin{array}{l}\text { Product } \\
\text { size (bp) }\end{array}$ & Reference(s) \\
\hline $\begin{array}{l}\text { Staphylococcus } \\
\text { aureus }\end{array}$ & $\begin{array}{l}\text { AAT CTT TGT CGG TAC ACG ATA TTC TTC ACG } \\
\text { CGT AAT GAG ATT TCA GTA GAT AAT ACA ACA }\end{array}$ & 108 bp & 1 \\
\hline S. epidermidis & $\begin{array}{l}\text { ATC AAA AAG TTG GCG AAC CTT TTC A } \\
\text { CAA AAG AGC GTG GAG AAA AGT ATC A }\end{array}$ & $124 \mathrm{bp}$ & 1 \\
\hline S. saprophyticus & $\begin{array}{l}\text { AAC GGG CGT CTC GAT AGA AAA } \\
\text { AAC GGG CGT CCA CAA AAT CA }\end{array}$ & $380 \mathrm{bp}$ & 1 \\
\hline $\begin{array}{l}\text { E. faecalis } \\
\quad \text { ddl }\end{array}$ & $\begin{array}{l}\text { 5'-ATCAAGTACAGTTAGTCTTTATTAG-3' } \\
\text { 5'-ACGATTCAAAGCTAACTGAATCAGT-3 }\end{array}$ & 941bp & 4 \\
\hline $\begin{array}{l}\text { E. faecium } \\
\quad \text { ddl }\end{array}$ & $\begin{array}{l}\text { 5'-TTGAGGCAGACCAGATTGACG-3' } \\
\text { 5'-TATGACAGCGACTCCGATTCC-3 }\end{array}$ & $658 \mathrm{bp}$ & 4 \\
\hline $\begin{array}{l}\text { klebsiella } \\
\text { pneumoniae }\end{array}$ & $\begin{array}{l}\text { GCAAGTCGAGCGGTAGCACAG } \\
\text { CAGTGTGGCTGGTCATCCTCTC }\end{array}$ & $260 \mathrm{bp}$ & 17 \\
\hline $\begin{array}{l}\text { Acinetobacter } \\
\text { baumannii }\end{array}$ & $\begin{array}{l}\text { AATTTACAGTGGCACATTAGGTCCC } \\
\text { GCAGAGATACCAGCAGAGATACACG }\end{array}$ & 722bp & 29 \\
\hline $\begin{array}{l}\text { Pseudomonas } \\
\text { aeruginosa }\end{array}$ & $\begin{array}{l}\text { ATGATCGTACAAATTGGTCGG } \\
\text { GTCATGAAACCGCCAGTC }\end{array}$ & $600 \mathrm{bp}$ & 29 \\
\hline
\end{tabular}




\section{RESULTS}

Of 818 nosocomial isolates collected from different wards, 335 (41\%) were staphylococci species consisting of 203 (25\%) S. aureus, 77 (9\%) S. epidermidis, 53 (7\%) S. saprophyticus and two other staphylococci species. Other isolates detected in clinical samples were $E$. faecalis $(\mathrm{n}=65,8 \%), E$. faecium $(\mathrm{n}=26,3 \%), K$. pneumoniae $(\mathrm{n}=179$, $22 \%), P$. aeruginosa $(\mathrm{n}=112,14 \%)$ and $A$. baumannii $(\mathrm{n}=101,12 \%)$.

According to the results of the antimicrobial susceptibility testing, the frequency of methicillin resistance (mecA gene) among $S$. aureus, $S$. epidermidis and $S$. saprophyticus isolates was $60 \%, 43 \%$ and $24 \%$, respectively. Nevertheless, no isolate was resistance to vancomycin (vanA and vanB), meropenem, chloramphenicol, ofloxacin and norofloxacin (Table 3). Although frequency of E. faecalis isolates was more than that of E. faecium, higher rate of antibiotic resistance was observed against the E. faecium isolates. All vancomycin-resistant strains carried vanA gene, while $v a n B$ and $v a n C$ genes were not detected (Table 3). The highest and lowest resistance rates in both species were recorded against tetracycline and linezolid, respectively. We isolated $112 P$. aeruginosa strains from samples collected from nosocomial infections. The highest and lowest resistance rates in these isolates were recorded against cefotaxime $(50 \%)$ and collistin (1\%), respectively. In addition, resistance rate against ceftriaxone, ceftazidime, cefepime, cefexime, ciprofloxacin, imipenem, meropenem, aztreonam, and gentamicin was $30 \%, 22 \%, 10 \%, 14 \%, 3 \%, 32 \%, 15 \%, 5 \%$ and $20 \%$, respectively. According to results of the DDST, $24 \%$ of all $P$. aeruginosa isolates were ESBL strains.

Table 2- Sequences of the primers used for detection of target genes in PCR assay

\begin{tabular}{|c|c|c|c|}
\hline Target & Primer sequence $\left(5 \_-3 \_\right)$ & $\begin{array}{l}\text { Product } \\
\text { size (bp) }\end{array}$ & Reference(s) \\
\hline mecA & $\begin{array}{l}\text { ACTGCTATCCACCCTCAAAC } \\
\text { CTGGTGAAGTTGTAATCTGG }\end{array}$ & $163 \mathrm{bp}$ & 2 \\
\hline $\operatorname{aac}\left(6^{9}\right) / \operatorname{aph}$ & $\begin{array}{c}\text { GAAGTACGCAGAAGAGA } \\
\text { ACATGGCAAGCTCTAGGA }\end{array}$ & 491bp & 2 \\
\hline $\operatorname{aph}(3)$-III a & $\begin{array}{l}\text { AAATACCGCTGCGTA } \\
\text { CATACTCTTCCGAGCAA }\end{array}$ & 242bp & 2 \\
\hline ant (4')-1a & $\begin{array}{l}\text { AATCGGTAGAAGCCCAA } \\
\text { GCACCTGCCATTGCTA }\end{array}$ & 135bp & 2 \\
\hline $\operatorname{van} A$ & $\begin{array}{l}\text { 5'-GGGAAAACGACAATTGC-3' } \\
\text { 5'-GTACAATGCGGCCGTTA-3' }\end{array}$ & 732bp & 3 \\
\hline $\operatorname{van} B$ & $\begin{array}{l}\text { 5'-ATGGGAAGCCGATAGTC-3 } \\
5 \text {-GATTTCGTTCTTCGACC-3 }\end{array}$ & 635bp & 3 \\
\hline $\operatorname{vanC}$ & $\begin{array}{l}\text { GGTATCAAGGAAACCTC } \\
\text { CTTCCGCCATCATAGCT }\end{array}$ & 822 bp & 3 \\
\hline ermB & $\begin{array}{l}5 \text { - CGACGAAACTGGCTAAAATAAGTAAAC - } \\
\text { GAGGTATGGCGGGTAAGTTTTATTAAG }\end{array}$ & 408bp & 31 \\
\hline tetM & $\begin{array}{l}5 \text { - GGACAAAGGTACAACGAGGAC - } 3 \\
5 \text { - GGTCATCGTTTCCCTCTATTACC }-3\end{array}$ & 445bp & 31 \\
\hline $\operatorname{tet}(\mathrm{L})$ & $\begin{array}{l}\text { CCTGCGAGTACAAACTGG } \\
\text { TCAAGGTAACCAGCCAAC }\end{array}$ & 1209bp & 31 \\
\hline OXA-2 & $\begin{array}{l}\text { AAGAAACGCTACTCGCCTGC } \\
\text { CCACTCAACCCATCCTACCC }\end{array}$ & $478 \mathrm{bp}$ & 29 \\
\hline OXA-10 & $\begin{array}{l}\text { GTCTTTCGAGTACGGCATTA } \\
\text { ATTTTCTTAGCGGCAACTTAC }\end{array}$ & $720 \mathrm{bp}$ & 18 \\
\hline qnrA & $\begin{array}{l}\text { 5'-TCAGCAAGAGGATTTCTCA-3 } \\
\text { 5'-GGCAGCACTATTA CTCCCA-3 }\end{array}$ & 516 bp & 30 \\
\hline qnrB & $\begin{array}{l}\text { 5'-ATG ACG CCA TTA CTG TAT AA-3', } \\
\text { 5'-GAT CGC AAT GTG TGA AGT TT }-3 \text { ', }\end{array}$ & 562 bp & 30 \\
\hline qnrC & $\begin{array}{l}\text { ATTACGGGTTGTAATTTGTCTTATG } \\
\text { ATCAGAAAATGATCCCCTACT }\end{array}$ & 144 bp & 30 \\
\hline qnrS & $\begin{array}{l}\text { CAATCATACATATCGGCACC } \\
\text { TCAGGATAAACAACAATACCC }\end{array}$ & 642 bp & 30 \\
\hline
\end{tabular}


Table 3- The frequency of multidrug resistance among clinical isolates from hospitals of Zahedan, Iran

\begin{tabular}{|c|c|c|}
\hline Species & $\begin{array}{l}\text { Number } \\
\text { isolates }\end{array}$ & of Multi drug resistance pattern \\
\hline \multirow{6}{*}{ S. aureus } & 11 & OXA-ERY-TET \\
\hline & 4 & OXA-GM-KAN-ERY \\
\hline & 3 & OXA-GM-KAN-TET \\
\hline & 3 & OXA-ERY-TET-CLI \\
\hline & 1 & OXA-GM-ERY-TET-SXT \\
\hline & 1 & OXA-GM-KAN-ERY-TET \\
\hline \multirow{5}{*}{ E. faecalis } & 6 & VAN-ERY-TET-GM-AMP-IMI \\
\hline & 2 & VAN-ERY-TET-GM-AMP-IMI-CIP \\
\hline & 1 & VAN-ERY-TET-GM-AMP-IMI-PIP \\
\hline & 1 & VAN-ERY-TET-GM-AMP-IMI-CIP-NIT \\
\hline & 1 & VAN-ERY-TET-GM-AMP-IMI-NIT \\
\hline \multirow{17}{*}{ E. faecium } & 2 & VAN-ERY-TET-GM-IMI-AMP-LIN-NIT-PIP-SYN-CIP-CHL \\
\hline & 2 & VAN-ERY-TET-GM-IMI-AMP-NIT-PIP-CIP \\
\hline & 1 & VAN-ERY-TET-GM-IMI-AMP-LIN-PIP-SYN-CIP-CHL \\
\hline & 1 & VAN-ERY-TET-GM-IMI-AMP-NIT-PIP-SYN-CIP-CHL \\
\hline & 1 & VAN-ERY-TET-GM-IMI-AMP-NIT-PIP-CIP-CHL \\
\hline & 1 & VAN-ERY-TET-GM-IMI-AMP-NIT-PIP-CIP-FOS \\
\hline & 1 & VAN-ERY-TET-GM-IMI-AMP-NIT-CIP-FOS \\
\hline & 1 & VAN-ERY-TET-GM-IMI-AMP-NIT-CIP \\
\hline & 1 & VAN-ERY-TET-GM-IMI-AMP-PIP-CIP \\
\hline & 1 & VAN-ERY-TET-GM-IMI-AMP-NIT-PIP \\
\hline & 1 & VAN-ERY-TET-GM-IMI-NIT-CIP \\
\hline & 1 & VAN-ERY-TET-GM-IMI-NIT-CIP-FOS \\
\hline & 1 & VAN-ERY-TET-GM-IMI-AMP \\
\hline & 1 & VAN-ERY-TET-GM-IMI-AMP-CIP \\
\hline & 1 & VAN-ERY-TET-GM-IMI-NIT \\
\hline & 1 & VAN-ERY-TET-GM-IMI-PIP \\
\hline & 1 & VAN-ERY-TET-GM-IMI-AMP-FOS \\
\hline \multirow[t]{5}{*}{ Species } & $\begin{array}{l}\text { Number of } \\
\text { isolates }\end{array}$ & MDR pattern \\
\hline & 39 & AMP-GM-CEFO-SXT \\
\hline & 17 & AMP-GM-CEFO \\
\hline & 6 & AMP-GM-CEFO-SXT-IMI-CEFP-CIP-NOR \\
\hline & 5 & AMP-GM-CEFO-SXT-CIP-NOR \\
\hline \multirow{14}{*}{ K. pneumoniae } & 5 & AMP-GM-CEFO-SXT-IMI \\
\hline & 4 & AMP-GM-CEFO-CEFP-IMI \\
\hline & 4 & AMP-GM-CEFO-CEFP \\
\hline & 4 & AMP-GM-CEFO-CIP-NOR \\
\hline & 3 & AMP-GM-CEFO-SXT-IMI-CEFP \\
\hline & 2 & AMP-GM-CEFO-IMI \\
\hline & 1 & AMP-GM-CEFO-CEFP-NOR \\
\hline & 1 & AMP-GM-CEFO-CEFP-CIP \\
\hline & 7 & AMP-OXA-PIP-CEFO-CEFP-СTX-CEFE-IMI-GM \\
\hline & 6 & AMP-OXA-PIP-CEFO-CEFP-CTX-IMI-GM \\
\hline & 5 & AMP-OXA-PIP-CEFO-CEFP-CTX-IMI \\
\hline & 5 & AMP-OXA-PIP-IMI \\
\hline & 4 & AMP-OXA-CEFO-CEFP-СТX-CEFE \\
\hline & 3 & AMP-OXA-PIP-CEFO-CTX-CAZ \\
\hline \multirow[t]{11}{*}{ P. aeruginosa } & 2 & AMP-OXA-PIP-CEFO-CTX-IMI \\
\hline & 1 & AMP-OXA-PIP-CEFO-CEFP-IMI-CIP \\
\hline & 1 & AMP-OXA-PIP-CTX-CEFE-IMI-MER \\
\hline & 1 & AMP-OXA-PIP-CEFO-CTX-COL \\
\hline & 1 & AMP-OXA-PIP-CEFO-CEFP-CTX-IMI-AZT \\
\hline & 1 & AMP-OXA-CEFP-CTX-CEFE \\
\hline & 1 & AMP-OXA-CEFO-CAZ-CEFE \\
\hline & 10 & AMP-OXA-CEFE-CEFO-CTX-AZT-GM-CIP-CAZ-IMI-MER-TOB \\
\hline & 8 & AMP-OXA-CEFE-CEFO-CTX-AZT-GM-CIP-CAZ-IMI-MER-PIP \\
\hline & 7 & AMP-OXA-CEFE-CEFO-CTX-AZT-GM-CIP-CAZ-IMI-PIP \\
\hline & 7 & AMP-OXA-CEFE-CEFO-CTX-AZT-GM-CIP-CAZ-IMI-CEFP \\
\hline \multirow[t]{12}{*}{ A. baumannii } & 6 & AMP-OXA-CEFE-CEFO-CTX-AZT-GM-CIP-IMI-MER-TOB \\
\hline & 5 & AMP-OXA-CEFE-CEFO-CTX-AZT-CIP-CAZ-IMI-MER-PIP \\
\hline & 5 & AMP-OXA-CEFE-CEFO-CTX-AZT-GM-CIP-CAZ-CEFP \\
\hline & 1 & AMP-OXA-CEFE-CEFO-CTX-AZT-GM-CIP-CAZ-IMI \\
\hline & 1 & AMP-OXA-CEFE-CEFO-CTX-AZT-CIP-CAZ-PIP-CEFP \\
\hline & 1 & AMP-OXA-CEFE-CEFO-CTX-GM-CAZ-CEFP \\
\hline & 1 & AMP-OXA-CEFE-CEFO-CTX-AZT-GM-PIP \\
\hline & 1 & AMP-OXA-CEFE-CTX-AZT-CEFP \\
\hline & 1 & AMP-OXA-CEFE-CEFO-CTX-IMI-MER-PIP-TOB \\
\hline & 1 & AMP-OXA-CEFE-CEFO-CTX-AZT-GM-CIP-CAZ-IMI-MER-TOB \\
\hline & 1 & AMP-OXA-CEFE-CEFO-CTX-IMI \\
\hline & 1 & AMP-OXA-CEFE-CEFO-CTX-GM-CIP-CEFP \\
\hline
\end{tabular}

VAN: vancomycin; AMP: ampicillin; IMI: imipenem; ERY: erythromycin; TET: tetracycline; CHL: chloramphenicol; FOS: fosfomycin, LIN: linezolid; NIT: nitrofurantoin; PIP: piperacillin; AZT: azteronam; CTX: ceftriaxone; CAZ: ceftazidime; CEFP: cefepime; CEFO: cefotaxine; CEFE: cefexime; CIP: ciprofloxacin, gatifloxacin, norofloxacin, levofloxacin, ofloxacin, nalidixic acid; SXT: cotrimoxazole; MER: meropenem; GM: gentamicin; AN: amikacin; TOB: tobramycin; KAN: kanamycin 


\section{DISCUSSION}

Nosocomial infections are associated with significant risk of mortality and increased treatment cost (10). Microorganisms that are able to survive in the hospital environment can enter the body through wounds, catheters and ventilators. Gram-negative bacilli are important pathogens that are becoming increasingly resistant to most available antibiotics $(10,11)$.

In this study, 392 gram-negative and 424 gram-positive bacteria were isolated from samples collected from different parts of four hospitals in Zahedan, Iran. The most prevalent gram-negative and gram-positive bacteria were $K$. pneumoniae and $S$. aureus, respectively. One of the main causes of nosocomial infections is A. baumannii, which has recently become resistant to majority of $\beta$-lactam antibiotics $(12,13)$. The results of the present study showed that $24 \%$ of Acinetobacter strains isolated from outpatients in Zahedan produced ESBL. As seen in figure 3, all Acinetobacter isolates were resistant to ampicillin and oxacillin, while the rate of ciprofloxacin, imipenem, aztreonam and gentamicin resistance was $68 \%, 65 \%, 74 \%$ and $69 \%$, respectively. The lowest antibiotic resistance rate was associated with colistin $(5 \%)$, indicating the high value of this antibiotic for the treatment of infections caused by Acinetobacter.

In a study by Dashm et al. in India, of $137 \mathrm{~A}$. baumannii isolates, $74 \%$ were MDR and all isolates were susceptible to colistin (14). In the present study, $56 \%$ of isolates were MDR and $95 \%$ of isolates were sensitive to colistin. In another study in India, $87 \%$ of $A$. baumannii isolates from ICU patients were MDR (15). In a study by Gulbadakh et al. on 75 A. bumannii strains in Turkey, the rate of resistance to ceftazidime, ampicillin, gentamicin and ciprofloxacin was $89 \%, 97 \%, 66 \%$ and $97.3 \%$, respectively (16).

In our study, of 45 ESBL-positive isolates, the $O X A-2$ gene was present in 12 cases, the $O X A$ 10 gene was found in five cases and four case contained both genes. In a study by Rahimzadeh et al. in Iran on 60 ESBL-positive isolates, the $O X A-2$ and $O X A-10$ genes were present in seven and five isolates, respectively. $P$. aeruginosa is also among the main causes of hospital-acquired infections. Our results showed that $P$. aeruginosa is mostly resistant to cefotaxime and highly susceptible to colistin and tobramycin. In the present study, 24\% of the strains were ESBL. According to previous studies, frequency of ESBL genes in $P$. aeruginosa was highest in in China (17) and Iran (18). Of 24 ESBL-positive isolates, six isolates contained the $O X A-2$ gene, three had the $O X A-10$ gene and one isolate was positive for both genes. In a study in Iran, $68.7 \%$ of ESBL-positive isolates were positive for the OXA-10 gene (18). In a study by Frédéric Bert et al., $26.3 \%$ and $4.6 \%$ of isolates contained the $O X A-10$ and $O X A-1$, respectively (19).

Fluoroquinolones are a group of synthetic antibacterial that are widely used to treat bacterial infections. In the present study, the rate of nalidixic acid and ciprofloxacin resistance in $K$. pneumoniae isolates was $31.5 \%$ and $18.4 \%$, respectively. The high rate of nalidixic acid resistance may be because the production of this antibiotic dates back to 1962 (20).In addition, the rate of resistance to second generation fluoroquinolones norfloxacin and ofloxacin was $17.3 \%$ and $4.3 \%$, respectively. In line with these results, Madani et al. in Kermanshah (west of Iran) (20), Molaabaszadeh in Tabirz (Northeast) (21) and Kehrenberg in Spain (22) reported the rate of resistance to norfloxacin as $31.3 \%$, $29 \%$ and $33 \%$, respectively. In our study, the lowest rate of resistance was related to gatifloxacin, which is a new generation (fourth generation) fluoroquinolone with more potent antibacterial effects than the old fluoroquinolone.

There are three types of plasmid-dependent quinolone resistance genes (23). In the present study, we investigated $q n r$ genes types A, B, C and $\mathrm{S}$ and found qnrA, qnrB and qnrS in $17.7 \%, 48.8 \%$ and $8.88 \%$ of isolates, respectively. Moreover, we detected simultaneous presence of $q n r A$ and $B$ and $q n r B$ and $S$ in $13 \%$ and $11 \%$ of the isolates, respectively. However, qnrC was not found in any of the quinolone generators.

In a study by Pakzad et al. (2011), 20.8\% of $E$. coli isolates from the Milad Hospital in Tehran were $q n r B$ positive (24). In a study in Khorramabad (west of Iran), qnrA was detected in $14.3 \%$ of $E$. coli isolates (24). Given the increasing prevalence of these genes in $E$. coli strains in different regions of Iran and the possibility of horizontal gene transfer, accurate monitoring of fluoroquinolones administration seems essential. In a similar 
study in Jamaica, of $20 \mathrm{~K}$. pneumonia isolates, four strains contained $q n r A$, six strains carried both $q n r A$ and $q n r S$, and none contained $q n r B$ or $q n r S$ (25). In another study, of $37 \mathrm{~K}$. pneumoniae isolates, seven (18.92\%) isolates contained $q n r S$, while $q n r B$ was absent (23).

The nosocomial infections caused by MRSA and VRE strains are challenging because they are associated with treatment failure and mortality $(26,27)$. In the present study, the frequency of MRSS and MRSE strains was $24 \%$ and $43 \%$, respectively, which are similar to other studies (28). Vancomycin has been commonly used as the antibiotic of choice for the treatment of MRSA infections. Although a high rate of vancomycin resistance has been reported in some studies $(27,29)$, we observed no such phenomenon in our study. Multiple reports have shown that there is a high prevalence of MDR gram-positive bacteria in the hospital setting $(29,30)$. Similar to recent reports (3), we detected MDR enterococci isolates from clinical specimens. The most

\section{REFERENCES}

1. Khazaei S, Khazaei S, Ayubi E. Importance of prevention and control of nosocomial infections in Iran. Iran J Public Health. 47(2):307-308.

2. Stiller A, Schroder C, Gropmann A, Schwab F, Behnke $\mathrm{M}$, Geffers $\mathrm{C}$, et al. ICU ward design and nosocomial infection rates: a cross-sectional study in Germany. J Hosp Infect. 2017; 95(1): 71-75. doi: 10.1016/j.jhin.2016.10.011.

3. Vasquez V, Ampuero D, Padilla B. Urinary tract infections in inpatients: that challenge. Revista espanola de quimioterapia : publicacion oficial de la Sociedad Espanola de Quimioterapia. 2017; 30 Suppl 1: 39-41.

4. Cookson B, Morrison D, Marples R. Antibiotic resistance. Nosocomial gram-positive infection. Journal of medical microbiology. 1997; 46(6): 439-42.

5. Leroy $\mathrm{O}$, Beuscart $\mathrm{C}$, Mouton Y. Gram-negative nosocomial infection: incidence, pathogens, compromised host. British journal of clinical practice Supplement. 1988; 57: 27-35.

6. Qiao M, Ying GG, Singer AC, Zhu YG. Review of antibiotic resistance in China and its environment. Environ Int. 2018; 110: 160-172. doi: 10.1016/j.envint.2017.10.016.

7. Holmes AH, Moore LS, Sundsfjord A, Steinbakk M, Regmi S, Karkey A, et al. Understanding the mechanisms and drivers of antimicrobial resistance. Lancet. 2016; 387(10014): 176-87. doi: 10.1016/S01406736(15)

8. Cifuentes M, Silva F, Arancibia JM, Rosales R, Ajenjo MC, Riedel G, et al. Grupo Colaborativo de Resistencia Bacteriana, Chile: recommendations 2014 towards the control of bacteria resistance. Rev Chilena Infectol. 2015; 32(3): 305-18. doi: 10.4067/S071610182015000400008 . 00473-0. common UTI-related Enterococcus species was E. faecium.

\section{CONCLUSION}

Our findings indicate the relatively high frequency of ESBLs, MRSA and VRE strains in clinical isolates from hospitals of Zahedan, southeast of Iran. Horizontal gene transfer and mobile genetic elements can contribute to spread of antibiotic resistance genes in the community and hospitals. In this regard, a global surveillance plan should be coordinated for prevention of this overwhelming increase in emergence of antibiotic resistant bacteria.

\section{ACKNOWLEDGEMENTS}

The authors appreciate all individuals at Zahedan University of Medical Sciences who helped us in this study.

\section{CONFLICT OF INTEREST}

The authors declare that there is no conflict of interest.

9. Adamyan LV, Kuzmin VN, Arslanyan KN, Kharchenko EI. Spread of nosocomial infection in obstetric hospitals. Ter Arkh. 2015; 87(11): 109-112. doi: 10.17116/terarkh20158711109-112.

10. Danchaivijitrmd S, Dhiraputra C, Santiprasitkul S, Judaeng T. Prevalence and impacts of nosocomial infection in Thailand 2001. J Med Assoc Thai. 2005 Dec;88 Suppl 10:S1-9.

11. Perez F, Hujer AM, Hujer KM, Decker BK, Rather PN, Bonomo RA. Global challenge of multidrugresistant Acinetobacter baumannii. Antimicrobial agents and chemotherapy. 2007; 51(10): 3471-84.

12. Zarrilli R, Crispino M, Bagattini M, Barretta E, Di Popolo A, Triassi M, et al. Molecular epidemiology of sequential outbreaks of Acinetobacter baumannii in an intensive care unit shows the emergence of carbapenem resistance. Journal of clinical microbiology. 2004; 42(3):946-53.

13. Dash M, Padhi S, Pattnaik S, Mohanty I, Misra P. Frequency, risk factors, and antibiogram of Acinetobacter species isolated from various clinical samples in a tertiary care hospital in Odisha, India. Avicenna J Med. 2013; 3(4): 97-102.

14. Sinha N, Agarwal J, Srivastava S, Singh M. Analysis of carbapenem-resistant Acinetobacter from a tertiary care setting in North India. Indian J Med Microbiol. 2013; 31(1): 60-3.

15. Gulbudak H, Aslan G, Tezcan S, Ersoz G, Ulger M, Otag F. Investigation of the clonal relationship between nosocomial Acinetobacter baumannii isolates by RepPCR. Mikrobiyol Bul. 2014; 48(2): 316-24. 
16. Lee S, Park YJ, Kim M, Lee HK, Han K, Kang CS, et al. Prevalence of Ambler class $A$ and $D$ betalactamases among clinical isolates of Pseudomonas aeruginosa in Korea. J Antimicrob Chemother. 2005; 56: 122-7.

17. Chanawong A, M'Zali FH, Heritage J, Lulitanond A, Hawkey PM. SHV-12, SHV-5, SHV-2a and VEB-1 extended-spectrum beta-lactamases in Gram-negative bacteria isolated in a university hospital in Thailand. $\mathrm{J}$ Antimicrob Chemother. 2001; 48(6): 839-52.

18. Tayebeh F, Amani J, Moradyar M, Mirhossaini SA. Detection of Klebsiella Pneumoniae 16s rDNA Specific Gene by PCR-ELISA Technique. J Fasa Univ Med Sci. 2016; 5(4): 542-550.

19. Celenza G, Pellegrini C, Caccamo M, Segatore B, Amicosante G, Perilli M. Spread of blaCTX-M-type and blaPER-2 B-Lactamase genes in Clinical isolates from Bolivian hospitals. J Antimicrobial Chemotherapy. 2006; 57(5): 975-8.

20. Madani H, Khazaee S, Kanani M, Shahi M. Antibiotic Resistance Pattern of E.coli Isolated from Urine Culture in Imam Reza Hospital Kermanshah-2006 (Persian). Behbood Journal. 2008; 12(3): 287-95.

21. Molaabaszadeh H, Hajisheikhzadeh B, Mollazadeh M, Eslami K, Mohammadzadeh Gheshlaghi N. Study of Sensibility and Antimicrobial Resistance in Escherichia coli Isolated from Urinary Tract Infection in Tabriz City. JFUMS. 2013; 3 (2):149-154.

22. Kehrenberg $\mathrm{C}$, Friederichs $\mathrm{S}$, de Jong A. Identification of the plasmid-borne quinolone resistance gene qnrS in Salmonella enterica serovar Infantis. J Antimicrob Chemother. 2006; 58(1): 18-22.

23. Cai X, Li C, Huang J, Li Y. Prevalence of plasmidmediated quinolone resistance qnr genes in Central China. African Journal of Microbiology Research. 2011 Apr 18;5(8):975-8.
24. Pakzad I, Ghafourian S, Taherikalani M, Sadeghifard 25. Stephenson S, Brown PD, Holness A, Wilks M. The Emergence of Qnr-Mediated Quinolone Resistance among Enterobacteriaceae in Jamaica. West Indian Med J. 2010; 59(3): 241-4.

26. Namvar AE, Bastarahang S, Abbasi N, Ghehi GS, Farhadbakhtiarian S, Arezi P, et al. Clinical characteristics of Staphylococcus epidermidis: a systematic review. GMS Hyg Infect Control. 2014; 9(3): Doc23.doi: 10.3205/dgkh000243.

27. Zhang S, Sun X, Chang W, Dai Y, Ma X. Systematic Review and Meta-Analysis of the Epidemiology of Vancomycin-Intermediate and Heterogeneous Vancomycin-Intermediate Staphylococcus aureus Isolates. PloS one. 2015; 10(8): $\mathrm{e} 0136082$.

28. Ho PL, Lo PY, Chow KH, Lau EH, Lai EL, Cheng $\mathrm{VC}$, et al. Vancomycin MIC creep in MRSA isolates from 1997 to 2008 in a healthcare region in Hong Kong. The Journal of infection. 2010; 60(2): 140-5.

29. Yan JJ, Tsai SH, Chuang CL, Wu JJ. OXA-type betalactamases among extended-spectrum cephalosporin-resistant Pseudomonas aeruginosa isolates in a university hospital in southern Taiwan. J Microbiol Immunol Infect. 2006; 39(2): 130-4.

30. Guillard T, Moret H, Brasme L, Carlier A, VernetGarnier V, Cambau E, et al. Rapid detection of qnr and qepA plasmid-mediated quinolone resistance genes using real-time PCR. Diagn Microbiol Infect Dis. 2011; 70(2): 253-9. doi: 10.1016/j.diagmicrobio.2011.01.004.

31. Wagenlehner E, Niemetz A, Naber G. Spectrum of pathogens and resistance to antibiotics in urinary tract infections and the consequences for antibiotic treatment: study of urology inpatients with urinary tract infections (1994-2001). Urologe A. 2003; 42(1): 13-25. 